Acta vet. scand. $1968,9,33-40$.

From the Department of Pathology, Veterinary College of Norway, Oslo.

\title{
PSEUDOMONAS INFECTIONS IN MINK WITH SPECIAL REFERENCE TO PSEUDOMONAS VASCULITIS IN PULMONARY LESIONS
}

\author{
By \\ Knut Nordstoga
}

\begin{abstract}
Vascular changes referred to as Pseudomonas vasculitis have been known for many years in humans. The vascular injury occurs in arteries and veins and appears to be pathognomonic of Pseudomonas infections (Hitschmann \& Kreibich 1897, Fraenkel 1906, 1912, 1922, Geppert et al. 1953, Markley et al. 1957, Forkner et al. 1958, Curtin et al. 1961, Margaretten et al. 1961, Rabin et al. 1961, Teplitz et al. 1964b, Teplitz 1965). The alterations in the vascular walls are characterized by pronounced basophilia caused by massive mural infiltration of bacteria and almost total necrosis of the vessel walls. The vascular lesions are unaccompanied by intramural inflammatory reaction, and the surrounding tissue is submitted to a hemorrhagic necrosis, while a distinct inflammatory response is usually absent. In the perivascular tissue a massive Gram-negative bacillary accumulation occurs, but bacteria are not ordinarily present intraluminally in contrast to septic emboli associated to other bacteria.

Pseudomonas infections accompanied by these characteristic vascular lesions occur in humans especially in gangrenous skin lesions (ecthyma gangraenosum), infected burn wounds and in patients suffering from leucemia who have been treated with steroids and antimetabolites (Forkner et al., Margaretten et al., Teplitz). The vascular damage is present in the primary site of infection as well as in metastatic visceral lesions though they occur more constantly in the primary location (Teplitz et al. 1963, cited by Teplitz 1965). Metastatic processes of macroscopic size
\end{abstract}


may occur in any organs but are frequently present in the lungs as subpleural, circumscribed infarct-like nodules (Forkner et al., Curtin et al., Rabin et al., Teplitz).

There seem to exist some obscurity and discrepancy as to the pathogenesis of the vascular alterations. Thus Margaretten et al. state that the vessel damage precedes the hemorrhagic necrosis after bacterial invasion of the vessel walls, while Teplitz claims that metastatic septic lesions are initiated at the capillary level and that massive transmural bacterial infiltration of the arteries and veins occurs centripetally from the necrotic perivascular tissue. According to the latter author the accompanying hemorrhagic necrosis in the surrounding tissue is rather attributable to a direct toxic effect of the bacilli than to the vasculitis per se.

In the present paper Pseudomonas vasculitis in pulmonary lesions in mink is described.

\section{MATERIAL AND METHODS}

The material was obtained from two outbreaks of Pseudomonas septicemia, the first known outbreak in Norway, which occurred in 1960, and the most serious outbreak in 1965, when 4000 animals died (25\% of the total number of animals). The last outbreak is briefly described in another paper (Kyrkjebø \& Nordstoga 1968). As the macroscopic lesions are reported elsewhere and also closely corresponded to the descriptions given by others (Knox 1953, Trautwein et al. 1962, Haagsma \& Pereboom 1965), the gross pathologic findings will not be reviewed here. The investigation comprises 46 animals, 20 from the first outbreak and 26 from the last one. The microscopic examination was conducted on formalin-fixed pieces of tissue, and the sections were stained with hematoxylin-eosin (H\&E), van Gieson, phosphotungstic acid hematoxylin (PTAH), Lendrum's acid picroMallory method, Gram, methylene blue and a modified Giemsa method (Teplitz et al. 1964b).

\section{RESULTS}

Lungs. No inflammatory changes were observed in peracute cases, and the bloody macroscopic appearance was due exclusively to hemorrhagic necrosis. The epithelium of smaller bronchia was partly desquamated and necrotic, while the walls of the greater bronchia, as the only structures, were intact. Bacilli 


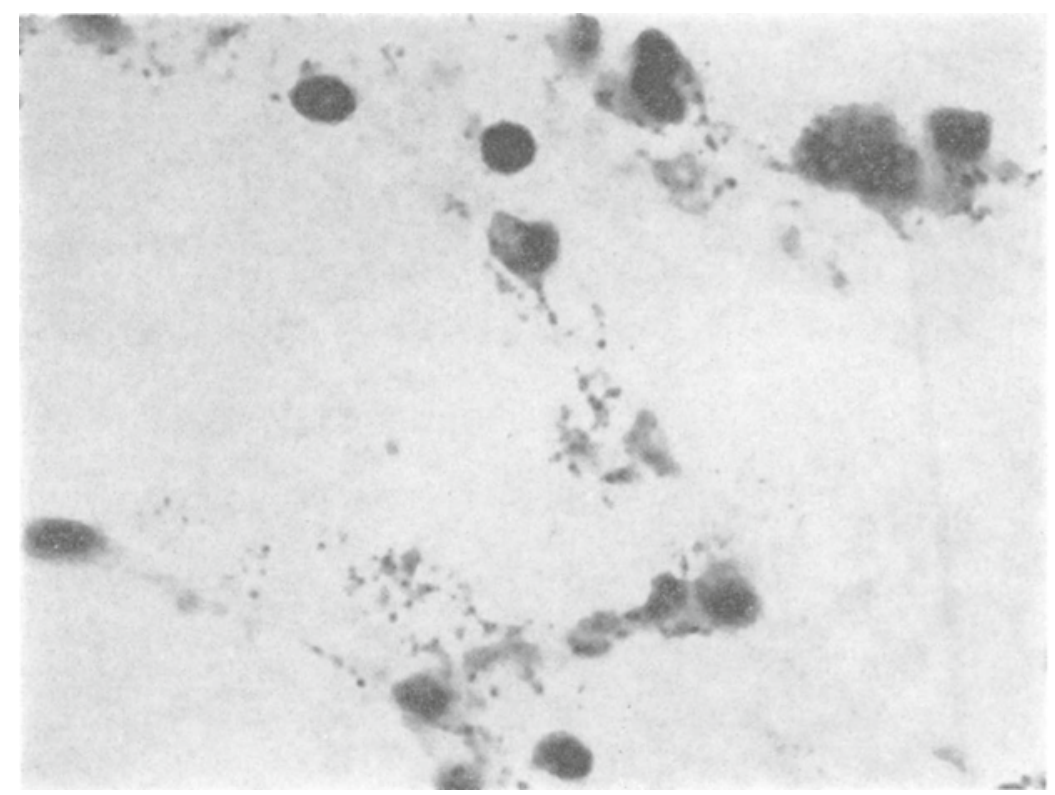

Figure 1. Bacilli within septal capillaries. Methylene blue, $\times 400$.

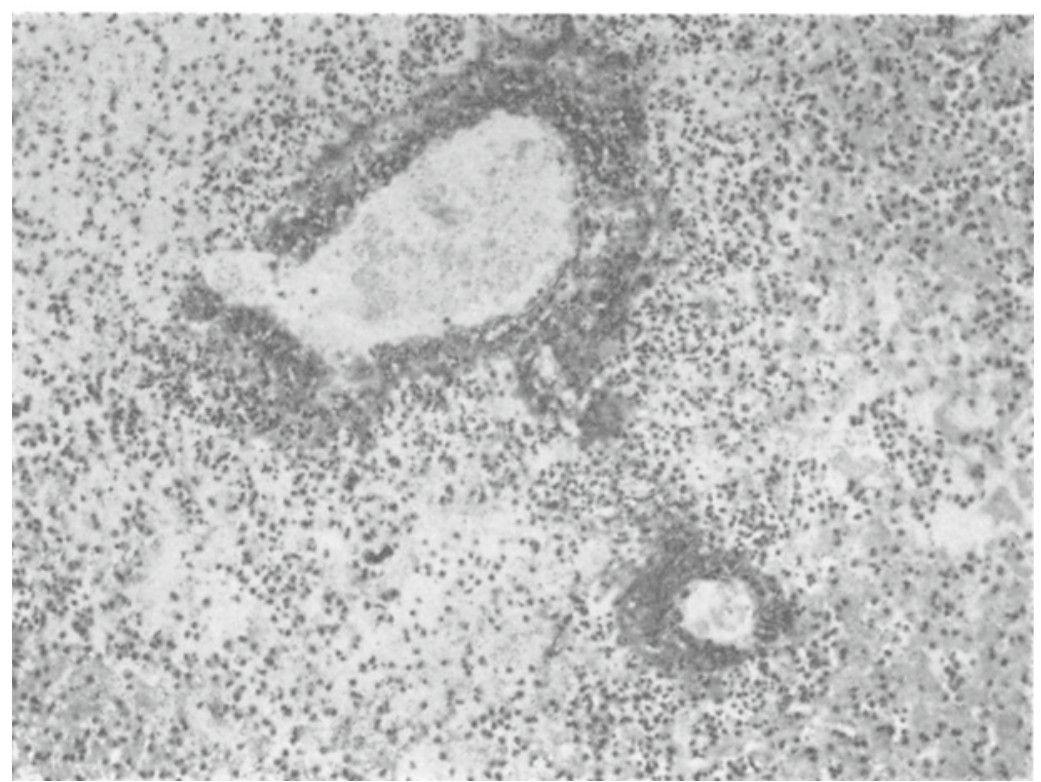

Figure 2. Necrosis of the vascular walls with mural bacillary accumulation and evident inflammatory response. Modified Giemsa stain, $\times 80$. 
were present in these peracute cases too, but by far not so numerous as in the instances where an inflammatory response was evident. In these latter cases the lung tissue contained myriads of bacteria. The rodshaped bacteria were in the incipient stage of involvement only demonstrated within the septal capillaries (Fig. 1). In H\&E-stained sections the vascular walls and perivascular parenchyma showed an intense basophilia due to densely packed bacteria. The perivascular accumulations of bacteria seemed sometimes to be localized within delicate spaces, but using routine technique it was impossible to decide whether these spaces were lymphatics or artifacts. In later stages of development neutrophilic infiltrations constantly occurred, sometimes showing a slight tendency to circumferential perivascular arrangement (Fig. 2). The vascular walls were necrotic, and in several vessels an almost total transmural bacillary penetration was observed. However, tunica elastica interna frequently appeared intact, and the lack of intravascular location of bacilli was obvious both in these and in less damaged vessels (Fig. 3). In later developmental stages the exudate constantly contained fibrin. Fibrin stained material was only occasionally observed in the walls of damaged vessels, and thrombosed vessels were a rarity. Scattered polymorphonuclear leucocytes adhering the intimal surface were occasionally observed, but bacteria could not be made visible inside these cells, and migration through the vascular endothelium could not be demonstrated.

Extrapulmonary changes. Distinct vascular changes were not found outside the lungs, nor were thrombi demonstrated in other organs. Congestion, hemorrhages and rods were found in various organs, but contrary to lung lesions, an inflammatory response was absent. Edematous transudations were sometimes seen in the heart muscle.

\section{DISCUSSION}

The pulmonary lesions accompanying Pseudomonas septicemia in mink start as a hemorrhagic necrosis of the lung tissue and develop rapidly to a hemorrhagic and fibrinous pneumonia. This pulmonary lesions is hardly compatible to any known pneumonia in other animals.

The pathogenesis as to the development of the pulmonary alterations cannot be fully elucidated by studying the histologic pattern. It has been difficult in experimental work to induce 
Pseudomonas septicemia by other modes of transmission than by aerogenous exposure (Kull 1965). It seems a likely assumption that in any way the peracute cases presented in this material were caused by an aerogenous infection followed by septicemia. However, the bacilli primarily appeared in septal capillaries in some cases which were considered to be less acute, and in these instances a hematogenous infection may possibly have occurred. Further, it seems likely to assume that the two Pseudomonas strains represented in the material under discussion were rather different in their pathogenic properties since the peracute necrotic and hemorrhagic pulmonary injury without any inflammatory response preferentially occurred in the second outbreak, while the characteristic Pseudomonas vasculitis was noted only in the first instance. The clinical manifestations and, as already mentioned, most experimental studies indicate an aerogenous infection (Trautwein et al. 1962, Kull), though septicemia has also been induced in other ways (Knox 1953, Trautwein et al.). Also from studying the microscopic pulmonary lesions, an aerogenous as well as hematogenous bacterial entrance seems possible, perhaps depending on the virulence or other differences between the strains of bacteria. Some dissimilarities in the histopathologic pattern from other descriptions (Knox, Trautwein et al.) may also possibly indicate that the microscopic pulmonary lesions partly depend on the strains. Under any circumstance, it seems a likely assumption that the lungs act as target organs in Pseudomonas septicemia in mink, contrary to what is the case in humans and laboratory animals, where the pulmonary lesions usually occur as metastatic processes following a septicopyemic condition.

The leucocytic reaction in pulmonary lesions accompanying some cases of Pseudomonas septicemia in mink is possibly more evident than in other species as judged from available descriptions, where the changes are frequently referred to as hemorrhagic necrosis without any inflammatory response.

In experimental Pseudomonas infections in rats it has been shown that initially a peripheral leucocytosis occurs followed by a diminution of the circulating leucocytes due to a maturation arrest of marrow neutrophils (Teplitz et al. 1964a). However, all instances included in the present material must obviously be regarded as acute cases, and thus the distinct leucocytic reaction observed in some animals does not necessarily indicate a different 
mode of reaction in mirk than in other species. The perivascular leucocytic accumulations demonstrated in some lung sections may rather be interpreted as caused by positive chemotaxis than as a consequence of local emigration of leucocytes through the vessel walls. As a conclusion it must be emphasized that the pulmonary lesions observed in the present material do not indicate that the characteristic vascular alterations accompanying Pseudomonas infections precede the injury in the surrounding tissue. The pulmonary lesions are more reasonably attributable to a direct toxic effect of bacilli as claimed by Teplitz (1965), rather than to the vasculitis. The microscopic findings do not indicate that disseminated intravascular coagulation plays any role in the development of pulmonary lesions in mink in contrast to what is seen in cases of Pseudomonas infection in humans (McKay 1965).

\section{REFERENCES}

Curtin, J. A., R. G. Petersdorf \& I. L. Bennett: Pseudomonas bacteriemia: Review of 91 cases. Ann. intern. Med. 1961, 54, 1077-1107.

Forkner, C. E., E. Frei, J. H. Edgcomb \& J. P. Utz: Pseudomonas septicemia. Observations on twenty-three cases. Amer. J. Med. 1958, 25, 877-899.

Fraenkel, E.: Uber Allgemeininfektionen durch den Bacillus pyocyaneus. Virchows Arch. path. Anat. 1906, 183, 405-440.

Fraenkel, E.: Uber die Menschenpathogenität des Bacillus pyocyaneus. Z. Hyg. Infekt.-Kr. 1912, 72, 486-522.

Fraenkel, E.: Ein weiterer Beitrag zur Menschenpathogenität des Bacillus pyocyaneus. Z. Hyg. Infekt.-Kr. 1922, 95, 125-134.

Geppert, L. J., H. J. Baker, B. I. Copple \& E. J. Pulaski: Pseudomonas infections in infants and children. J. Pediat. 1953, 41, 555-561.

Haagsma, J. \& W. J. Pereboom: Pseudomonas aeruginosa als oorzaak van een enzoötische infectie op een nertsenfarm. T. Diergeneesk. 1965, 90, 1093-1100.

Hitschmann, F. \& K. Kreibich: Zur Pathogenese des Bacillus pyocyaneus und zur Aetiologie des Ekthyma gangraenosum. Wien. klin. Wschr. 1897, 10, 1093-1101.

Knox, B.: Pseudomonas aeruginosa som årsag til enzootiske infeksjoner hos mink. Nord. Vet.-Med. 1953, 5, 731-760.

Kull, K.-E.: Något om sjukdomar under 1964. Våra pälsdjur 1965, 36, $45-47$.

Kyrkjebø, A. \& K. Nordstoga: Pseudomonasinfeksjon hos mink. Medlemsbl. norske Vet.-foren. 1968. (To be published). 
Margaretten, W., N. Hisayo \& B. H. Landing: Significance of selective vasculitis and bone marrow syndrome in Pseudomonas septicemia. New. Engl. J. Med. 1961, 265, 773-776.

Markley, K., G. Gurmendi, P. M. Chavez \& A. Bazan: Fatal Pseudomonas septicemia in burned patients. Ann. Surg. 1957, 145, 175-181.

McKay, D. G.: Disseminated intravascular coagulation. An intermediary mechanism of disease. Hoeber medical division. Harper Row, New York, Evanston \& London, 1965, p. 95-97.

Rabin, E. R., C. D. Graber, E. H. Vogel jr., R. A. Finkelstein \& W. A. Tumbusch: Fatal Pseudomonas infection in burned patients: a clinical, bacteriologic and anatomic study. New Engl. J. Med. 1961, 265, 1225-1231.

Teplitz, C.: Pathogenesis of Pseudomonas vasculitis and septic lesions. Arch. Path. (Chicago) 1965, 80, 297-307.

Teplitz, C., D. Davis, A. D. Mason jr. \& J. A. Moncrief: Pseudomonas burn wound sepsis. I. Pathogenesis of experimental Pseudomonas burn wound sepsis. J. surg. Res. 1964a, 4, 200-216.

Teplitz, C., B. S. Epstein, L. R. Rose \& J. A. Moncrief: Necrotizing tracheitis induced by tracheostomy tube: Pathogenesis. Arch. Path. (Chicago) 1964b, 77, 14-27.

Trautwein, G., C. F. Helmboldt \& S. W. Nielsen: Pathology of Pseudomonas pneumonia in mink. J. Amer. vet. med. Ass. 1962, 140, $701-704$.

\section{SUMMARY}

Pulmonary lesions associated with Pseudomonas infections in mink were studied histologically. In peracute cases the injury consisted of hemorrhagic necrosis of the lung tissue. In later stages of progression the widespread hemorrhagic necrosis was followed by leucocytic infiltration and exudation of fibrin. These latter changes also included classic Pseudomonas vasculitis such as this vascular lesion is described in humans and some laboratory animals.

\section{ZUSAMMENFASSUNG}

Pseudomonas-Infektion bei Nerzen im besonderen Hinblick auf Pseudomonas-Vaskulitis bei den Lungenveränderungen.

Die Lungenveränderungen im Anschluss an eine PseudomonasInfektion bei Nerze wurden histologisch untersucht. Die Veränderungen zeigten sich in perakutten Fällen als hämorrhagische Nekrosen im Lungengewebe. In einigen späteren Stadien entstanden reaktive Entzündungsprozesse mit einer Infiltration von Leukozyten sowie Exudation von Fibrin im Lungengewebe. Diese letzteren Veränderungen umfassten ausserdem klassische Pseudomonas-Vaskulitis entsprechend dem Gefässleiden, welches bei Menschen und einzelnen Versuchstieren beschrieben worden ist. 


\section{SAMMENDRAG}

Pseudomonas-infeksjon hos mink med spesielt henblikk på Pseudomonas-vaskulitt $i$ lungeforandringene.

Lungeforandringene i forbindelse med Pseudomonas-infeksjon hos mink er unders $\varnothing$ kt histologisk. Forandringene besto i perakutte tilfeller av hemorrhagisk nekrose av lungevevet. I noe senere stadier oppsto det reaktive betennelsesprosesser med infiltrasjon av leucocytter og eksudasjon av fibrin i lungevevet. Disse siste forandringene omfattet også klassisk Pseudomonas-vaskulitt slik denne karskade er beskrevet hos menneske og enkelte fors $\varnothing \mathrm{ksdyr}$.

(Received November 21, 1967). 


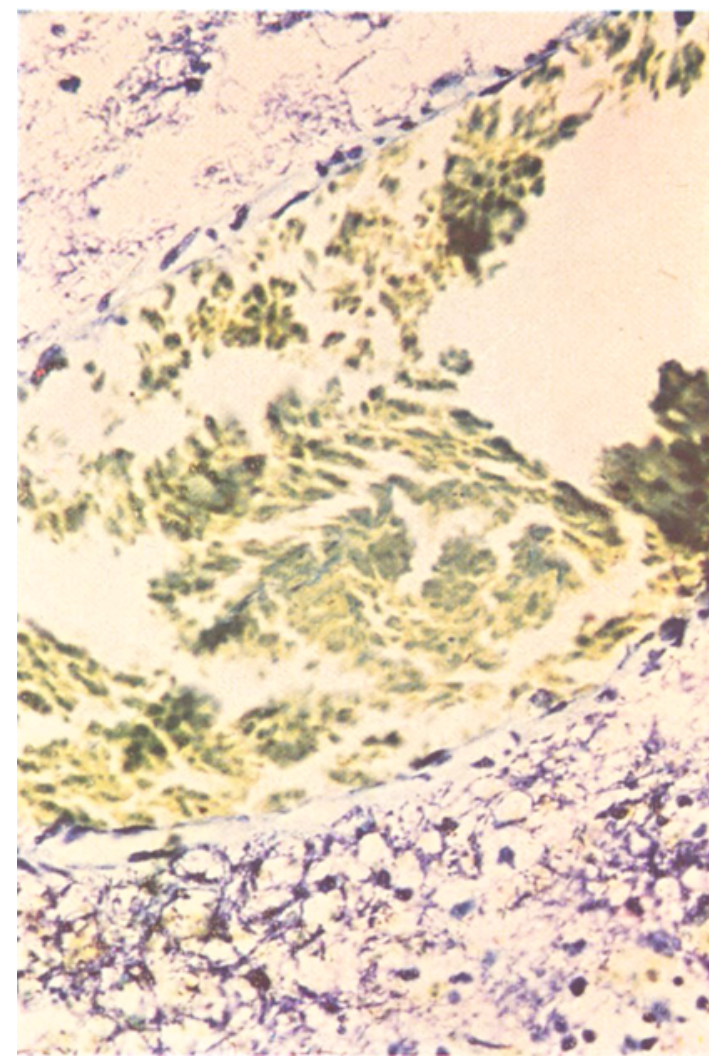

Figure 3. Necrotic vessel wall and intramural infiltration of bacteria. Note intact endothelium and absence of bacilli intraluminally. Methylene blue, $\times 110$. 
